DOI https://doi.org/10.18551/rjoas.2017-11.55

\title{
THE EFFECT OF SINGLE AND DUAL INFECTIONS OF CITRUS TRISTEZA VIRUS AND CITRUS VEIN ENATION VIRUS ON CITRUS SPECIES
}

\author{
Dwiastuti Mutia Erti* \\ Indonesian Citrus and Subtropical Fruits Research Institute, Indonesia \\ Handoko Rose Novita Sari \\ Faculty of Agriculture, University of Brawijaya, Indonesia \\ *E-mail: $\underline{\text { mutiaed@gmail.com }}$
}

\begin{abstract}
Viral diseases caused by CTV and CVEV induce dwarfing on plants and severe damage and yield loss to the citrus crop. The virus transmitted through infected plant material and by the same vectors, aphid. Problems cited in the field are complex of symptoms of the two diseases that are difficult to distinguish. This study aimed to determine the effect of single and dual infections of CTV and CVEV on Purut (Citrus hystrix) and Lime (Citrus aurantifolia). The research was conducted at the screen house and laboratory of Balitjestro, Batu and University of Brawijaya in October 2014 to April 2015. CTV and CVEV isolates used were from Balitjestro's collection. Treatments conducted were single inoculation for CTV and CVEV, 3 combinations of CTV and CVEV dual inoculation. Each treatment was carried out both on Purut and Lime. A total of 6 treatments and 5 replications were arranged in a Randomized Complete Design; each replication comprised of two plants. The results showed that the symptoms on Purut appeared faster and more severe than those on Lime. Both single and dual infections of CTV and CVEV affected the incubation period of CTV on vein clearing symptoms, cupping and vein enation. Symptom of vein clearing was found the fastest at dual infections treatment of CTV followed by CVEV. Cupping symptom was seen the fastest in the treatment of dual infections of CVEV followed by CTV, and symptom of vein enation was found only in a single infection of CVEV. The highest disease intensity and infection of vein clearing and cupping were observed on dual infections of CVEV followed by CTV while the highest infections of vein clearing and stem pitting were obtained from simultaneous dual infection of CTV and CVEV. The results of serologic testing by DAS ELISA on three observations (44 days after inoculation (dai), 86 dai, and 142 dai) showed that a dual-infection showed greater absorbance value than single infection treatment did. Plants growths on dual infections treatment were slower than those on single infection.
\end{abstract}

\section{KEY WORDS}

Citrus histrix, Citrus aurantifolia, Citrus Tristeza Virus, Citrus Vein Enation Virus.

Most citrus germplasms in Indonesia are from other citrus-producing country, either from Asia, Australia, America, and Africa which were introduced through plant materials. These plant materials may pose risk to the citrus cultivation due to possible transmission of viral pathogens carried by the plant material. At the beginning of citrus free disease program in 1987, there were seven diseases specified dangerous and must be cleared through in vitro Shoot Tip Grafting (STG), namely CVPD (Citrus Vein Phloem Degeneration) / HLB (Huanglungbin), CTV (Citrus Tristeza virus), CVEV (Citrus Vein Enation Virus), CPsV (Citrus Psorosis Virus), CEV (Citrus Exocortis Viroids), CTLV (Citrus Tater Leaf Virus) and CCaV (Citrus Caxhexia Viroids) (Supriyanto \& Whittle 1997). Then in 2011, there were two diseases (CTLV and CcaV) omitted from hazardous status since they showed no threat in Indonesia, which leaves the other five still in that dangerous status (Dwiastuti, 2016). Similar programs have been conducted in other countries, for example in India (Sharma et al. 2007), Taiwan (Su 2008), Croatia (Hančević et al. 2009), Italy (Meziane et al., 2009), USA 
(Vidalakis et al. 2013), Cambodia (Setha \& Su 2011), as well as many other countries with their respective main virus diseases.

In clonal citrus seed production, protection against those diseases already put into practice though not fully implemented. The heavy inter-region seed distribution is suspected to not fully used the disease-free plant materials. There are still many illegal seeds distributed causing diseases to be found in the field most of the time. From the results of a survey in Riau Seed Centers in 2014, it was discovered that the seeds used by farmers were without disease-free label. $66,7 \%$ of Budwood Multiplication Block (BMB) maintained without screenhouse and mother plant population in the field were infected by CTV and $100 \%$ seeds from small nursery were also infected by CTV as well as CVPD in smaller amount (Dwiastuti \& Wuryantini, 2014).

Currently, the complex of CTV and CVEV symptoms are frequently found in the field, thus rising concern of crop damage and loss of production. The two viruses spread through infected plant material and with the same aphid vectors (Toxoptera citricida, T. Aurantii, Aphis spaerocola, A.gosypii). As it is known, CTV and endemic CVEV are very difficult to control in the field when vectors are dominan and the shoots are always available.

Almost all citrus species and their hybrids, citrus showing stem pitting symptom, most lime, grapefruit and some sweet orange are susceptible to CTV (EPPO / CABI 1996), while citrus that are susceptible to CVEV are Rough lemon (Citus jamhiri), sour orange (C. aurantium), lime (C. aurantifolia), Purut (C. histrix), sweet orange (C. sinensis) and satsuma (C. unshiu) (EPPO / CABI 1996a).

Symptoms of CTV infection are characterized by damage to phloem, showing the indentation or extending notch on the wood tissue of trunk, branches or twigs (stem pitting) and vein clearing in the form of dotted or elongated lines in the translucent vein, 2 weeks to 2 months after infection. Plants grow poorly, dwarf with small leaves. In some cases, leaves become rigid with edges curved upwards (cupping). Other symptoms that may appear is the "vein crocking" (Dwiastuti 2016). CVEV can cause woody galls on rough lemon rootstock, and vein enation on Rough Lemon, Mexican Lime and sour orange (da Graça et al. 2007). Vein enation appears as a lateral bulge at the bottom of the leaves and hollows on the top surface. Vein enation has more striking symptoms in Mexican Lime and sour orange than on rough lemon, sweet orange, mandarin, and grapefruit. In field conditions, only sour orange and Mexican Lime showed heavy vein enation. Research on single and dual infections of CTV and CVEV has never been done on Purut (Citrus hystrix); CTV and CVEV tests usually use lime (Citrus aurantifolia) as an indicator. Therefore, it is necessary to investigate the viruses' effect on the severity of symptoms and growth of the plants.

\section{MATERIALS AND METHODS OF RESEARCH}

Research was conducted in screen house and laboratory of Balitjestro, Batu and Brawijaya University in October 2014 to April 2015. The two viruses studied were CTV and CVEV isolates from Balitjestro's collection with three treatments: single inoculation of CTV, single inoculation of CVEV and three combinations on dual inoculation of CTV and CVEV which were 1) CTV inoculation, followed by CVEV inoculation after one month, 2) CVEV inoculation, followed by CTV inoculation after 1 month, and 3) simultaneous inoculation of CTV and CVEV. Each treatment was done in Purut and Lime. Research was arranged in a completely randomized design (CRD) with 6 treatments and 5 replications, each consisted of two plants. Inoculation was done by sticking the bark of infected plants. Parameters observed were incubation period, severity of CVEV and CTV symptoms, ELISA test, and plant growth (plant height, leaf number, leaf area).

The incubation period was observed every week which starts two weeks after inoculation until the appearance of the first symptoms. CTV symptoms observed were percentage of vein clearing, vein cupping, stem pitting, while symptoms of CVEV observed were vein enation, with intervals of 2 weeks up to 8 times from 4 weeks after inoculation. CTV and CVEV disease intensity calculated using following formula: 


$$
P=\frac{n}{N} \times 100 \%
$$

Where:

$\mathrm{P}=$ Percentage of disease $(\%)$;

$\mathrm{N}=$ number of plants showing vein clearing/cupping/vein enation /stem pitting;

$\mathrm{N}=$ total number of observed plant.

Serologic testing was conducted by Double Sandwich Enzyme Linked Immunosorbent Assay (ELISA DAS), performed three times at the beginning, middle, and end of observation. Elisa Kit for CTV (Agdia) was used to test whether there is CTV in the leaves. A total of $0.3 \mathrm{~g}$ of citrus leaf vein crushed in a solution of $3 \mathrm{~mL}$ buffer extract 1:25 g Tween-20, $1.0 \mathrm{~g}$ of nonfat milk / skim) in $250 \mathrm{~mL}$ of $1 \mathrm{X}$ PBST, $\mathrm{pH}$ 7.4. First, Elisa plate coated with100 $\mu \mathrm{L}$ of CTV coating antibody solution (100 ml coating buffer with $50 \mu \mathrm{L}$ of concentrated antibody 1: 200), incubated for two hours and rinsed with 1X PBST three times, three minutes each. Next, 100 $\mu \mathrm{L}$ of fluid sample was added in each determined plate hole along with a positive control and a negative control, then incubated overnight in the refrigerator $\left(4^{\circ} \mathrm{C}\right)$. After that, plate was washed with 1X PBST four times, three minutes each. $100 \mu \mathrm{L}$ solution of conjugate enzyme (alkaline phosphate conjugate (bottles $A$ and $B$ ) were mixed with the ECG buffer $(50 \mathrm{~mL} A$ and $50 \mathrm{~mL} B$ mixed with $10 \mathrm{ml}$ of ECL buffer). Plate was incubated at room temperature for 2 hours. Solution of the enzyme conjugat was removed, then plate rinsed with 1X PBST four times each, three minutes each. $100 \mu \mathrm{L}$ of PNP $1 \mathrm{mg} / \mathrm{mL}$ solution was added in each hole. The PNP solution was prepared by dissolving 1 tablet of PNP into $5 \mathrm{ml}$ substrate solution. This solution is enough for 8 rows of holes (96 holes). Solution then incubated for 30 minutes. Reaction was stop (to stabilize color formed) with $50 \mathrm{~mL}$ of $3 \mathrm{M}$ sodium hidroxide $(\mathrm{NaOH})$. The result was read using Elisa reader at $405 \mathrm{~nm}$ filter.

Plant height was determined by measuring the tip of the plant to the soil surface. The number of leaves was determined by counting all fully unfolded leaves at every branch of the tested plants. Observations for both parameters were done every two-week up to eight times. Leaf area was measured using a leaf area meter in the final observation. Data obtained from observations were analyzed using the $\mathrm{F}$ test at $5 \%$ level and then proceed with Honestly Significant Difference (HSD) test level of $5 \%$.

\section{RESULTS AND DISCUSSION}

Incubation period of CTV and CVEV on Purut and Lime. The incubation period of disease symptoms of CTV and CVEV in Lime occured faster than Purut. The fastest of vein clearing incubation period observed in dual simultaneous inoculations treatment, at 86 days after inoculation (dai) on both varieties, while cupping appeared on Lime at 86 dai in simultaneous inoculation treatment followed by dual inoculation treatment of CVEV then CTV and dual inoculation treatment of CTV then CVEV (98 dai), both in Lime.

Table 1 - Incubation period of CTV and CVEV symptoms on Purut (C.histrix) and Lime (C.aurantifolia)

\begin{tabular}{|c|c|c|c|c|c|c|c|c|}
\hline \multirow{2}{*}{ Treatment } & \multicolumn{3}{|c|}{ Incubation period on Purut (dai) } & \multicolumn{3}{c|}{ Incubation period on Lime (dai) } \\
\cline { 2 - 9 } & $\begin{array}{c}\text { Vein } \\
\text { clearing }\end{array}$ & cupping & $\begin{array}{c}\text { vein } \\
\text { enation }\end{array}$ & $\begin{array}{c}\text { Stem } \\
\text { pitting }\end{array}$ & $\begin{array}{c}\text { Vein } \\
\text { clearing }\end{array}$ & cupping & $\begin{array}{c}\text { vein } \\
\text { enation }\end{array}$ & $\begin{array}{c}\text { Stem } \\
\text { pitting }\end{array}$ \\
\hline Control (healthy plant) & 0 & 0 & 0 & 0 & 0 & 0 & 0 & 0 \\
\hline CTV single inoculation & 100 & 0 & 0 & 0 & 92 & 114 & 0 & 0 \\
\hline $\begin{array}{c}\text { CVEV single } \\
\text { inoculation }\end{array}$ & 0 & 0 & 86 & 0 & 0 & 0 & 100 & 0 \\
\hline $\begin{array}{c}\text { Dual inoculation, CTV } \\
\text { then CVEV }\end{array}$ & 128 & 0 & 0 & 0 & 0 & 98 & 100 & 0 \\
\hline $\begin{array}{c}\text { Dual inoculation, CVEV } \\
\text { then CTV }\end{array}$ & 128 & 142 & 0 & 0 & 0 & 98 & 60 & 0 \\
\hline $\begin{array}{c}\text { Simultaneous } \\
\text { inoculations of CTV } \\
\text { and CVEV }\end{array}$ & 86 & 0 & 0 & 140 & 86 & 86 & 135 & 0 \\
\hline
\end{tabular}


Symptom of vein enation was found the fastest in dual inoculation treatment of CVEV then CTV (44 dai) in Lime, followed by a single CVEV inoculation (86 dai) in Purut and 100 dai in Lime (Table 1). Symptoms of stem pitting was found only in Purut on dual simultaneous inoculation of CTV and CVEV at 140 dai.

Effect of single and dual inoculation on the expression of symptoms and the percentage of CTV and CVEV attack on two citrus species. Symptom of vein clearing was identified by changing appearance of the secondary or tertiary veins of leaves; there were dotted or elongated lines on translucent vein of leaves (Figure 1a, 1b). Leaf cupping showed symptom such as curving inward like a bowl (Figure 2a, 2b), stem pitting symptoms appeared on the twigs marked by horizontal lines and elongated curved which were clearly visible when the bark peeled (Figure 1d).
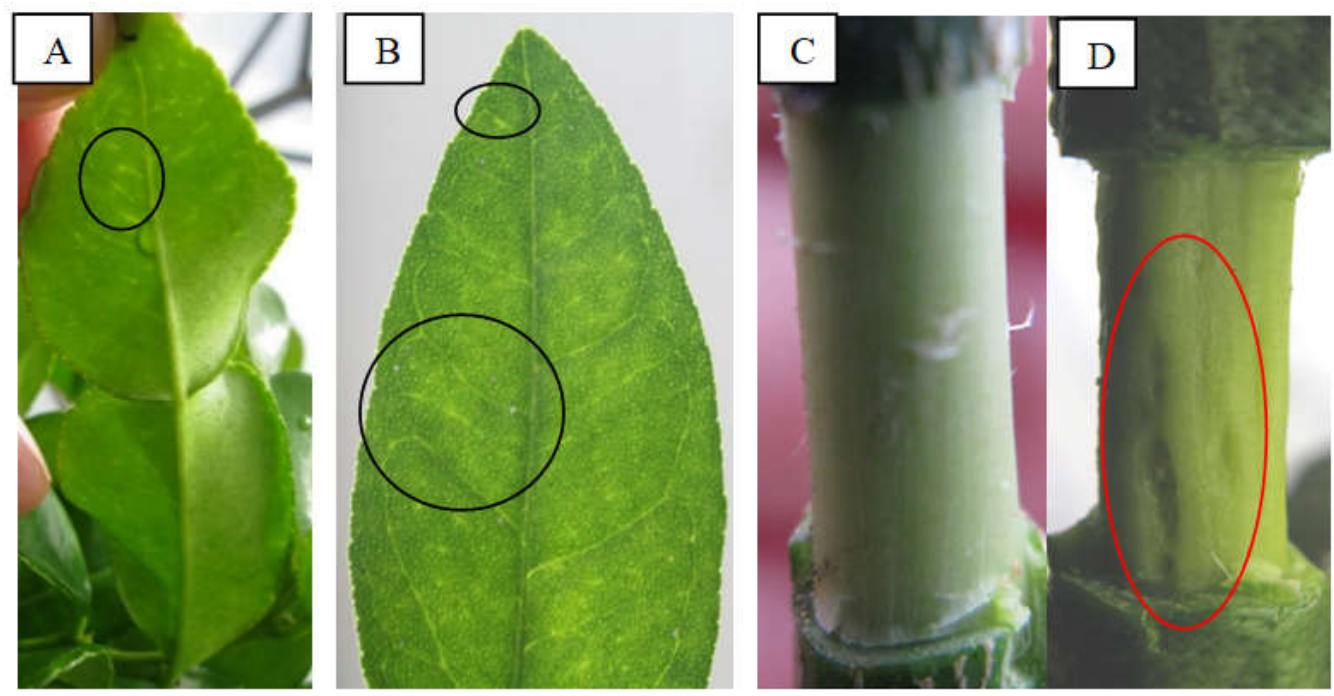

Figure 1 - Symptoms of vein clearing a) on leave of Purut, b) on top surface of secondary leave of Lime, c) healthy twig, d) twig showing stem pitting symptom

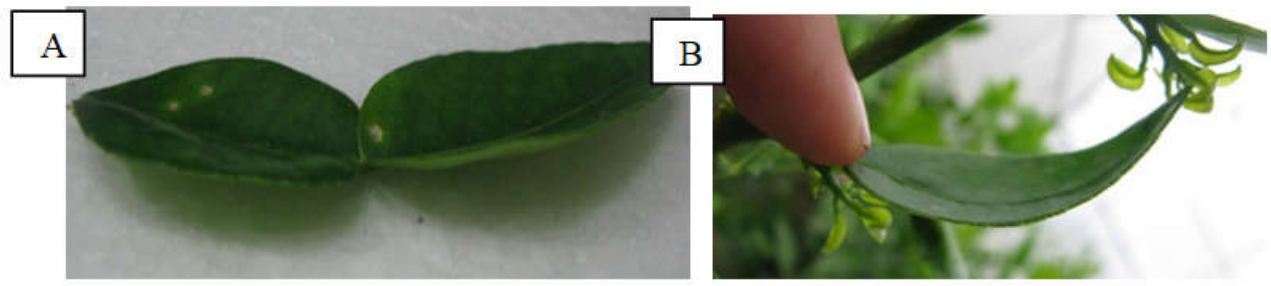

Figure 2 - Cupping symptom: a) on leave of Purut, b) on leave of Lime
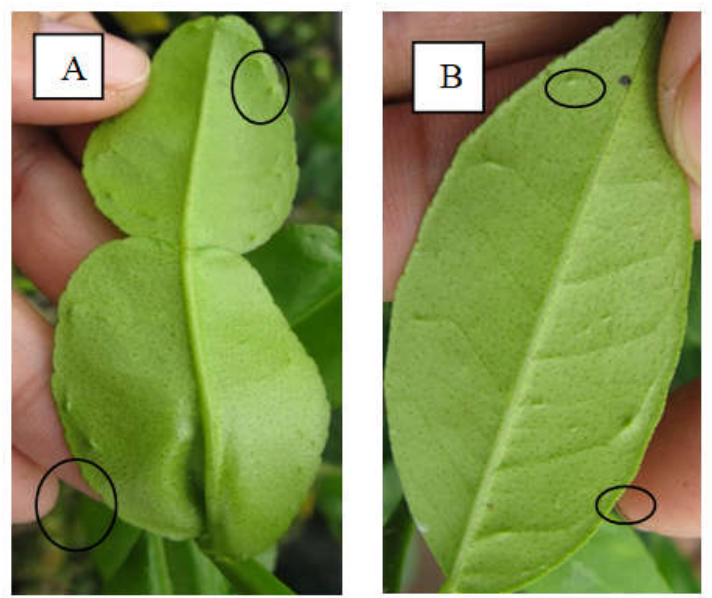

Figure 3 - Symptom of vein enation: a) on Purut, b) on Lime 
Enation vein symptoms characterized by the occurrence of enations (bulge) on the lower surface of the vein of secondary leaves and slightly concave top surface (Figure $3 a$, 3b). Symptoms of vein clearing and cupping were more obvious on Lime than on Purut (Figure $1 \mathrm{a}, 1 \mathrm{~b}$ and $2 \mathrm{a}, 2 \mathrm{~b}$ ), but symptoms of stem pitting only appeared on Purut (Figure 1d.). Both two citrus varieties showed vein enation symptoms (Figure 3). Plants infected by single inoculation of CTV only showed vein clearing symptom (Table 5) while plants infected by single CVEV inoculation only showed vein enation symptom (Table 7).

Symptoms of vein clearing in Lime were found the fastest and highest at simulatenous inoculation treatment which is also significantly different from other treatments except on the last observation, single CTV inoculation and dual inoculation of CTV then CVEV were faster (Table 5). Other treatments showed symptoms in observations on 128 dai, considered slow compared to previous studies. On Lime, vein clearing symptoms observed sooner in all three combinations of dual inoculation (at 100 dai) than on Purut (128 dai). Highest symptoms appeared on simultaneous inoculation treatment of CTV and CVEV.

Plants showing symptoms of cupping on Purut was found only in the treatment of dual inoculation of CVEV then CTV (at 142 dai), while in Lime, the symptoms were more abundant, namely at treatment of CTV single inoculation and three combinations of dual inoculation of CTV and CVEV (Table 6). Fastest infection (at 100 dai) and highest $(60 \%)$ were found in the treatment of CTV and CVEV simultaneous inoculations (Table 6).

Table 5 - The effect of single and dual inoculation of CTV and CVEV on the percentage of vein clearing showing symptom plants on two citrus spesies

\begin{tabular}{|c|c|c|c|c|c|c|c|c|c|c|}
\hline \multirow{2}{*}{ Treatment } & \multicolumn{10}{|c|}{ Percentage (\%) (day after inoculation) } \\
\hline & \multicolumn{2}{|c|}{86} & \multicolumn{2}{|c|}{100} & \multicolumn{2}{|c|}{114} & \multicolumn{2}{|c|}{128} & \multicolumn{2}{|c|}{142} \\
\hline \multicolumn{11}{|c|}{ Purut (C.histrix) } \\
\hline Control (healthy plant) & 0 & a & 0 & a & 0 & a & 0 & a & 0 & a \\
\hline CTV single inoculation & 0 & a & 0 & a & 0 & a & 20 & $\mathrm{~b}$ & 80 & $\mathrm{C}$ \\
\hline CVEV single inoculation & 0 & a & 0 & a & 0 & a & 0 & a & 0 & a \\
\hline Dual inoculation, CTV then CVEV & 0 & a & 0 & a & 0 & a & 30 & $\mathrm{~b}$ & 80 & $\mathrm{C}$ \\
\hline Dual inoculation, CVEV then CTV & 0 & $a$ & 0 & $a$ & 0 & $a$ & 30 & $\mathrm{~b}$ & 50 & $\mathrm{~b}$ \\
\hline Simultaneous inoculations of CTV and CVEV & 10 & $\mathrm{~b}$ & 30 & $\mathrm{~b}$ & 40 & $\mathrm{~b}$ & 50 & $\mathrm{C}$ & 70 & $\mathrm{bc}$ \\
\hline \multicolumn{11}{|c|}{ Lime (C.aurantifolia) } \\
\hline Control (healthy plant) & 0 & a & 0 & a & 0 & a & 0 & a & 0 & a \\
\hline CTV single inoculation & 0 & a & 20 & a & 25 & $\mathrm{~b}$ & 30 & $\mathrm{~b}$ & 40 & $\mathrm{~b}$ \\
\hline CVEV single inoculation & 0 & a & 0 & a & 0 & a & 0 & a & 0 & $\mathrm{a}$ \\
\hline Dual inoculation, CTV then CVEV & 0 & a & 10 & $\mathrm{a}$ & 20 & $a b$ & 25 & $a b$ & 30 & $\mathrm{~b}$ \\
\hline Dual inoculation, CVEV then CTV & 0 & a & 5 & a & 10 & $\mathrm{a}$ & 0 & $\mathrm{a}$ & 0 & a \\
\hline Simultaneous inoculations of CTV and CVEV & 20 & a & 30 & a & 45 & C & 55 & C & 75 & $\mathrm{C}$ \\
\hline
\end{tabular}

Mean followed by the same letters on the same column is not significantly different according to HSD test $5 \%$.

Table 6 - The effect of single and dual inoculation of CTV and CVEV on the percentage of cupping showing symptom plants on two citrus spesies

\begin{tabular}{|c|c|c|c|c|c|c|c|c|c|c|}
\hline \multirow{2}{*}{ Treatment } & \multicolumn{10}{|c|}{ Percentage (\%) (day after inoculation) } \\
\hline & \multicolumn{2}{|l|}{86} & \multicolumn{2}{|c|}{100} & \multicolumn{2}{|c|}{114} & \multicolumn{2}{|c|}{128} & \multicolumn{2}{|c|}{142} \\
\hline \multicolumn{11}{|c|}{ Purut (C.histrix) } \\
\hline Control (healthy plant) & 0 & $\mathrm{a}$ & 0 & $\mathrm{a}$ & 0 & a & 0 & a & 0 & a \\
\hline CTV single inoculation & 0 & a & 0 & a & 0 & a & 0 & a & 0 & a \\
\hline CVEV single inoculation & 0 & $a$ & 0 & $a$ & 0 & $a$ & 0 & a & 0 & a \\
\hline Dual inoculation, CTV then CVEV & 0 & $\mathrm{a}$ & 0 & a & 0 & a & 0 & $a$ & 0 & a \\
\hline Dual inoculation, CVEV then CTV & 0 & $\mathrm{a}$ & 0 & a & 0 & a & 0 & $a$ & 10 & $b$ \\
\hline Simultaneous inoculations of CTV and CVEV & 0 & $\mathrm{a}$ & 0 & a & 0 & a & 0 & a & 0 & a \\
\hline \multicolumn{11}{|c|}{ Lime (C.aurantifolia) } \\
\hline Control (healthy plant) & 0 & a & 0 & $\mathrm{a}$ & 0 & a & 0 & a & 0 & a \\
\hline CTV single inoculation & 0 & $\mathrm{a}$ & 0 & a & 15 & $\mathrm{~b}$ & 25 & $\mathrm{~b}$ & 35 & $\mathrm{~b}$ \\
\hline CVEV single inoculation & 0 & $\mathrm{a}$ & 0 & a & 0 & a & 0 & a & 0 & a \\
\hline Dual inoculation, CTV then CVEV & 0 & $\mathrm{a}$ & 15 & $\mathrm{~b}$ & 30 & c & 40 & C & 50 & $\mathrm{C}$ \\
\hline Dual inoculation, CVEV then CTV & 0 & $\mathrm{a}$ & 15 & $\mathrm{~b}$ & 20 & $\mathrm{~b}$ & 25 & $\mathrm{~b}$ & 35 & $\mathrm{~b}$ \\
\hline Simultaneous inoculations of CTV and CVEV & 10 & $\mathrm{~b}$ & 20 & $\mathrm{~b}$ & 25 & $\mathrm{bc}$ & 40 & C & 60 & C \\
\hline
\end{tabular}

Mean followed by the same letters on the same column is not significantly different according to HSD test $5 \%$ 
Plants showing symptom of vein enation on Purut were only found in CTV single inoculation, visibly increased linearly from 86 to 142 dai. On Lime, vein enation symptoms appeared in single CVEV treatment, as well as three combinations of dual inoculation with various percentages and were significantly different between treatments. Highest vein enation symptoms observed in dual inoculation CVEV then CTV, CVEV single inoculation, followed by dual inoclations CTV then CVEV and simultaneous inoculations treatment (Table 7).

Table 7 - The effect of single and dual inoculation of CTV and CVEV on the percentage of vein enation showing symptom plants on pada two citrus spesies

\begin{tabular}{|c|c|c|c|c|c|c|c|c|c|c|}
\hline \multirow{2}{*}{ Treatment } & \multicolumn{10}{|c|}{ Percentage (\%) (day after inoculation) } \\
\hline & \multicolumn{2}{|c|}{86} & \multicolumn{2}{|c|}{100} & \multicolumn{2}{|c|}{114} & \multicolumn{2}{|c|}{128} & \multicolumn{2}{|c|}{142} \\
\hline \multicolumn{11}{|c|}{ Purut (C.histrix) } \\
\hline Control (healthy plant) & 0 & a & 0 & a & 0 & a & 0 & a & 0 & a \\
\hline CTV single inoculation & 0 & a & 0 & a & 0 & a & 0 & $\mathrm{a}$ & 0 & $\mathrm{a}$ \\
\hline CVEV single inoculation & 20 & a & 20 & a & 30 & $\mathrm{~b}$ & 30 & $\mathrm{~b}$ & 50 & $\mathrm{~b}$ \\
\hline Dual inoculation, CTV then CVEV & 0 & $\mathrm{a}$ & 0 & $\mathrm{a}$ & 0 & $\mathrm{a}$ & 0 & $\mathrm{a}$ & 0 & $\mathrm{a}$ \\
\hline Dual inoculation, CVEV then CTV & 0 & a & 0 & $a$ & 0 & $a$ & 0 & $a$ & 0 & $a$ \\
\hline Simultaneous inoculations of CTV and CVEV & 0 & a & 0 & $\mathrm{a}$ & 0 & $\mathrm{~b}$ & 0 & a & 0 & $\mathrm{a}$ \\
\hline \multicolumn{11}{|c|}{ Lime (C.aurantifolia) } \\
\hline Control (healthy plant) & 0 & a & 0 & a & 0 & a & 0 & a & 0 & a \\
\hline CTV single inoculation & 0 & a & 0 & a & 0 & $\mathrm{a}$ & 0 & a & 0 & a \\
\hline CVEV single inoculation & 0 & $\mathrm{a}$ & 15 & $\mathrm{~b}$ & 20 & $\mathrm{bc}$ & 25 & $\mathrm{C}$ & 30 & $\mathrm{~b}$ \\
\hline Dual inoculation, CTV then CVEV & 0 & a & 10 & $\mathrm{~b}$ & 10 & $\mathrm{~b}$ & 10 & $\mathrm{~b}$ & 20 & $\mathrm{~b}$ \\
\hline Dual inoculation, CVEV then CTV & 0 & a & 30 & $\mathrm{C}$ & 35 & $\mathrm{C}$ & 40 & $\mathrm{~d}$ & 45 & $\mathrm{~b}$ \\
\hline Simultaneous inoculations of CTV and CVEV & 5 & $\mathrm{~b}$ & 15 & $\mathrm{~b}$ & 15 & $\mathrm{~b}$ & 15 & $\mathrm{~b}$ & 20 & $\mathrm{~b}$ \\
\hline
\end{tabular}

Mean followed by the same letters on the same column is not significantly different according to HSD test $5 \%$.

ELISA test of CTV. Elisa serology test using CTV antibody was performed three times at 44 dai (beginning), 88 dai (mid) and at 142 dai. The first test indicated that there were two dual inoculation treatments which were positive for the virus CTV in Purut (Table 8). In the second test, CTV was detected positive single inoculation of CTV. The absorbent value of positive resulted treatment showed increasing tendency at the subsequent test except in dual inoculation CVEV then CTV. Its absorbent value was small, less than twice as much PC value, indicating the samples did not contain CTV.

Table 8 - Result of ELISA on single and dual inoculation of CTV and CVEV on two citrus spesies

\begin{tabular}{|c|c|c|c|}
\hline \multirow{2}{*}{ Treatment } & \multicolumn{3}{|c|}{ Absorbent value of ELISA } \\
\hline & I (44 dai) & II (86 dai) & III (142 dai) \\
\hline \multicolumn{4}{|c|}{ Purut (C.histrix) } \\
\hline Control (healthy plant) & $-0,001(-)$ & $0,001(-)$ & $-0,001(-)$ \\
\hline CTV single inoculation & $-0,002(-)$ & $0,099(+)$ & $0,105(+)$ \\
\hline CVEV single inoculation & $0,007(-)$ & $0,000(-)$ & $-0,002(-)$ \\
\hline Dual inoculation, CTV then CVEV & $-0,001(-)$ & $0,100(+)$ & $0,111(+)$ \\
\hline Dual inoculation, CVEV then CTV & $0,032(+)$ & $0,101(+)$ & $0,097(+)$ \\
\hline Simultaneous inoculations of CTV and CVEV & $0,107(+)$ & $0,099(+)$ & $0,096(+)$ \\
\hline \multicolumn{4}{|c|}{ Lime (C.aurantifolia) } \\
\hline Control (healthy plant) & $-0,001(-)$ & $0,001(-)$ & $-0,001(-)$ \\
\hline CTV single inoculation & $0,032(+)$ & $0,100(+)$ & $0,127(+)$ \\
\hline CVEV single inoculation & $0,001(-)$ & $0,001(-)$ & $0,001(-)$ \\
\hline Dual inoculation, CTV then CVEV & $0,074(+)$ & $0,099(+)$ & $0,111(+)$ \\
\hline Dual inoculation, CVEV then CTV & $0,032(+)$ & $0,045(+)$ & $0,008(-)$ \\
\hline Simultaneous inoculations of CTV and CVEV & $0,054(+)$ & $0,0076(+)$ & $0,100(+)$ \\
\hline Grinding & blank & blank & blank \\
\hline $\mathrm{NC}$ & $-0,0015$ & 0,001 & $-0,008$ \\
\hline $\mathrm{PC}$ & 0,118 & 0,110 & 0,102 \\
\hline
\end{tabular}

Note: Measured with ELISA reader at $405 \mathrm{~nm}$. Threshold for a positive reaction on new plate> $2 x$ the negative. Control (Lamka, 1990). Negative (-) does not contain CTV and positive (+) contains CTV. 
Effect of single and dual inoculation of CTV and CVEV on Plant Growth. Result of observation on number of leaves from 44 to 142 dai showed significant difference among the treatments on Purut, but no significant difference on Lime. Highest number of leave was in control plant followed by single CVEV inoculation treatment and the least on single CTV inoculation treatment. Only few leaves were there on Lime plant at the beginning of the observation, and the growth was also slower than Purut (Table 9). The increase on number of leaves was fluctuating. The patterns were similar across treatments on Purut, rapid increase on the third to the fifth observation (58-72 dai) and the 13th to 15th (128- 142 dai) (Figure 3). The increase pattern in the number of leaves on the Lime varies between treatments. Highest increase on leaf number was from single inoculation of CTV (30.5) and dual inoculation CVEV then CTV (26.7) on the 13th to 15th observations (128-144 dai). Treatment of dual inoculation CVEV and CTV at 11-13 weeks (114-128 dai) showed highest increase of leaf number compared to other treatments, but went down in the next observation (Figure 4). The rate of Lime leaf growth at 9-11 weeks was actually decreased in all treatments.

Table 9 - Effect of treatment of single and dual inoculation of CTV and CVEV on number of leaves of two citrus species

\begin{tabular}{|c|c|c|c|c|c|c|c|c|}
\hline \multirow{2}{*}{ Treatment } & \multicolumn{8}{|c|}{ Number of leaves (dai) } \\
\hline & 44 & 58 & 72 & 86 & 100 & 114 & 128 & 142 \\
\hline \multicolumn{9}{|c|}{ Purut (C.histrix) } \\
\hline Control (healthy plant) & $22,50 \mathrm{~d}$ & $23,30 \mathrm{~d}$ & $46,50 \mathrm{~d}$ & $56,00 \mathrm{c}$ & $61,60 \mathrm{c}$ & $64,10 \mathrm{~d}$ & $65,90 \mathrm{~d}$ & $91,70 \mathrm{~d}$ \\
\hline CTV single inoculation & $14,60 \mathrm{~b}$ & $17,60 \mathrm{a}$ & $22,00 \mathrm{a}$ & $29,60 a$ & $30,60 \mathrm{a}$ & $30,70 \mathrm{a}$ & $31,00 \mathrm{a}$ & $42,50 \mathrm{a}$ \\
\hline CVEV single inoculation & $14,00 \mathrm{~b}$ & $17,20 \mathrm{a}$ & $28,70 \mathrm{~b}$ & $30,30 a$ & $32,50 \mathrm{a}$ & $41,40 \mathrm{bc}$ & $48,00 \mathrm{c}$ & $62,30 \mathrm{c}$ \\
\hline Dual inoculation, CTV then CVEV & $12,00 \mathrm{a}$ & $\begin{array}{c}20,00 \\
b c\end{array}$ & $28,60 \mathrm{~b}$ & $35,20 \mathrm{ab}$ & $35,20 a b$ & $36,50 \mathrm{ab}$ & $39,30 \mathrm{~b}$ & $50,60 \mathrm{~b}$ \\
\hline Dual inoculation, CVEV then CTV & $20,60 \mathrm{c}$ & $\begin{array}{c}21,60 \\
\mathrm{~cd}\end{array}$ & $\begin{array}{c}28,40 \\
a b\end{array}$ & 30,70 a & $33,10 a b$ & $38,70 \mathrm{bc}$ & $45,60 \mathrm{c}$ & $50,60 \mathrm{~b}$ \\
\hline $\begin{array}{l}\text { Simultaneous inoculations of CTV } \\
\text { and CVEV }\end{array}$ & $15,00 \mathrm{~b}$ & $\begin{array}{c}19,00 \\
a b\end{array}$ & $38,80 \mathrm{c}$ & $38,20 \mathrm{~b}$ & $40,70 \mathrm{~b}$ & $43,80 \mathrm{c}$ & $46,40 \mathrm{c}$ & $50,00 \mathrm{~b}$ \\
\hline \multicolumn{9}{|c|}{ Lime (C.aurantifolia) } \\
\hline Control (healthy plant) & $1,70 \mathrm{a}$ & $3,40 a$ & $9,70 a$ & $9,80 a$ & $11,40 \mathrm{a}$ & $17,10 \mathrm{a}$ & $27,80 \mathrm{a}$ & $37,80 a$ \\
\hline CTV single inoculation & $1,60 a$ & $2,70 a$ & $7,90 a$ & $12,20 a$ & $13,20 a$ & $14,30 a$ & $22,30 a$ & $52,80 a$ \\
\hline CVEV single inoculation & $0,50 a$ & $2,40 a$ & $7,00 a$ & $7,60 \mathrm{a}$ & $7,80 \mathrm{a}$ & $10,80 a$ & $23,10 a$ & $34,40 a$ \\
\hline Dual inoculation, CTV then CVEV & $0,90 \mathrm{a}$ & $4,30 \mathrm{a}$ & $8,90 a$ & $9,30 \mathrm{a}$ & $9,20 \mathrm{a}$ & $12,80 a$ & $38,20 \mathrm{a}$ & $53,40 a$ \\
\hline Dual inoculation, CVEV then CTV & $2,00 a$ & $4,00 a$ & $9,10 a$ & $12,80 a$ & $15,40 a$ & $14,40 \mathrm{a}$ & $24,80 a$ & $51,50 a$ \\
\hline $\begin{array}{l}\text { Simultaneous inoculations of CTV } \\
\text { and CVEV }\end{array}$ & $0,00 a$ & $0,80 a$ & $8,50 a$ & $14,30 a$ & $14,10 a$ & $14,10 a$ & $26,40 a$ & $55,70 a$ \\
\hline
\end{tabular}

Mean followed by the same letters on the same column is not significantly different according to HSD test $5 \%$.

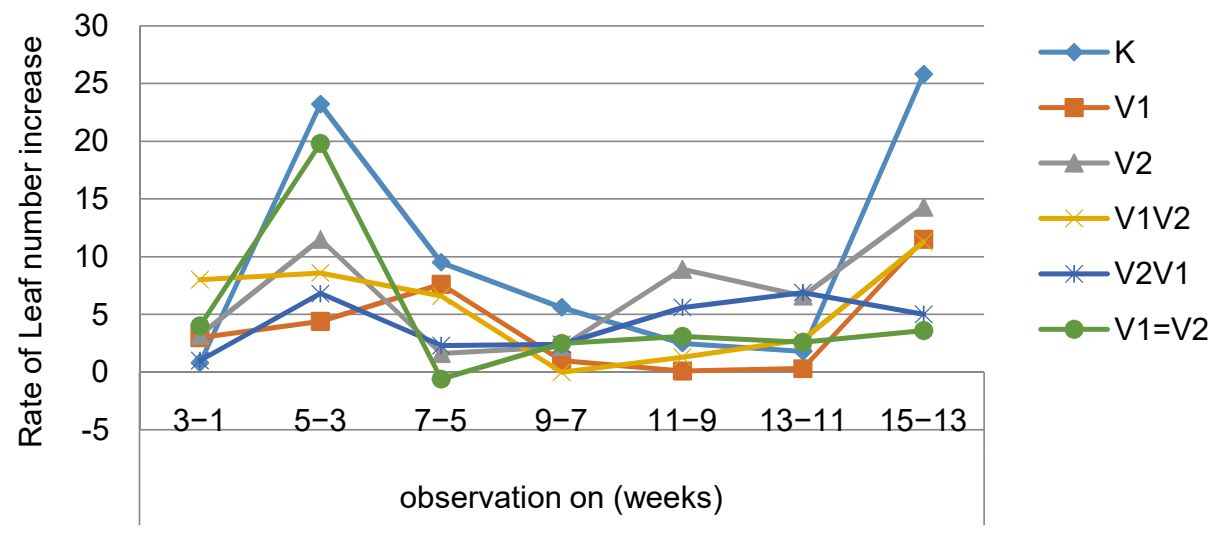

Figure 3 - Rate of leaf number increase on $C$. Histrix

Note: Control (K), single CTV inoculation (V1), single CVEV inoculation (V2), dual inoculation CTV then CVEV (V1V2), dual inoculation CVEV then CTV (V2V1), simultaneous inoculation of CTV and CVEV (V1=V2) 


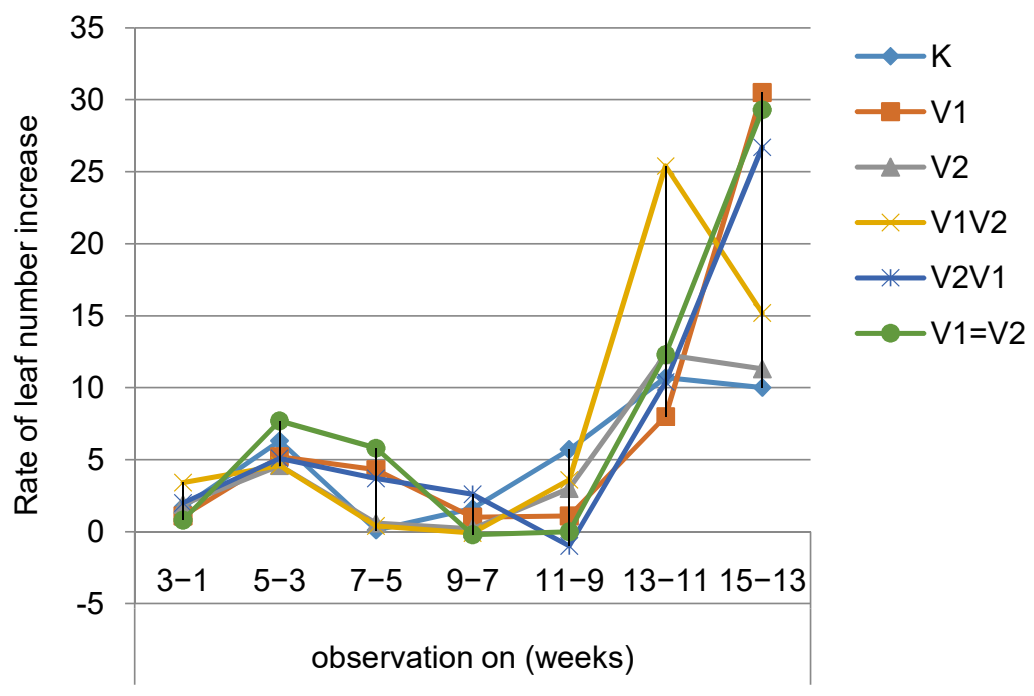

Figure 4 - Rate of leaf number increase on $C$. Aurantifolia

Note: Control (K), single CTV inoculation (V1), single CVEV inoculation (V2), dual inoculation CTV then CVEV (V1V2), dual inoculation CVEV then CTV (V2V1), simultaneous inoculation of CTV and CVEV (V1=V2)

Treatment of single and dual inoculation of CTV and CVEV influenced leaf area of Purut but not on Lime. Purut showed the smallest leaf area in dual inoculation treatment of CTV and CVEV followed by single inoculation of CTV and other combinations of dual inoculation (Table 10, Figure 5). Healthy control plants of Purut and Lime citrus showed the highest leaf area.

Table 10 - Effect of treatment of single and dual inoculation of CTV and CVEV on leaf area of two citrus species

\begin{tabular}{|c|c|c|}
\hline \multirow{2}{*}{ Treatment } & \multicolumn{2}{|c|}{ Leaf area (cm2) } \\
\cline { 2 - 3 } & C.histrix & C.aurantifolia \\
\hline Control (healthy plant) & $18,43 \mathrm{~b}$ & $13,75 \mathrm{a}$ \\
\hline CTV single inoculation & $15,24 \mathrm{ab}$ & $12,41 \mathrm{a}$ \\
\hline CVEV single inoculation & $16,12 \mathrm{~b}$ & $11,53 \mathrm{a}$ \\
\hline Dual inoculation, CTV then CVEV & $12,63 \mathrm{a}$ & $11,40 \mathrm{a}$ \\
\hline Dual inoculation, CVEV then CTV & $15,60 \mathrm{ab}$ & $10,03 \mathrm{a}$ \\
\hline Simultaneous inoculations of CTV and CVEV & $16,02 \mathrm{ab}$ & $9,14 \mathrm{a}$ \\
\hline
\end{tabular}

Mean followed by the same letters on the same column is not significantly different according to HSD test $5 \%$.

C. histrix $\quad$ C. aurantifolia

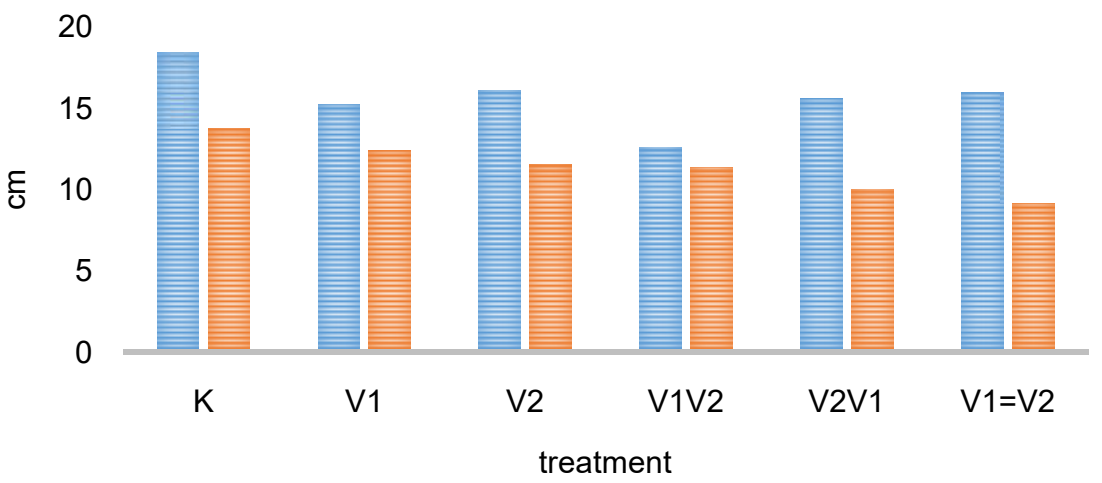

Figure 5 - Leaf area of two citrus spesies

Note: Control (K), single CTV inoculation (V1), Single, CVEV inoculation (V2), dual inoculation CTV then CVEV (V1V2), dual inoculation CVEV then CTV (V2V1), simultaneous inoculation of CTV and CVEV (V1=V2) 
Table 8 - Result of ELISA on single and dual inoculation of CTV and CVEV on two citrus spesies

\begin{tabular}{|l|c|c|c|}
\hline \multirow{2}{*}{ Treatment } & \multicolumn{3}{|c|}{ Absorbent value of ELISA } \\
\cline { 2 - 4 } & I (44 dai) & II (86 dai) & III (142 dai) \\
\hline \multicolumn{3}{|c|}{ Purut } & \multicolumn{3}{|c|}{} \\
\hline Control (healthy plant) & $-0,001(-)$ & $0,001(-)$ & $-0,001(-)$ \\
\hline CTV single inoculation & $-0,002(-)$ & $0,099(+)$ & $0,105(+)$ \\
\hline CVEV single inoculation & $0,007(-)$ & $0,000(-)$ & $-0,002(-)$ \\
\hline Dual inoculation, CTV then CVEV & $-0,001(-)$ & $0,100(+)$ & $0,111(+)$ \\
\hline Dual inoculation, CVEV then CTV & $0,032(+)$ & $0,101(+)$ & $0,097(+)$ \\
\hline Simultaneous inoculations of CTV and CVEV & $0,107(+)$ & $0,099(+)$ & $0,096(+)$ \\
\hline \multicolumn{3}{|l}{ Lime } \\
\hline Control (healthy plant) & $-0,001(-)$ & $0,001(-)$ & $-0,001(-)$ \\
\hline CTV single inoculation & $0,032(+)$ & $0,100(+)$ & $0,127(+)$ \\
\hline CVEV single inoculation & $0,001(-)$ & $0,001(-)$ & $0,001(-)$ \\
\hline Dual inoculation, CTV then CVEV & $0,074(+)$ & $0,099(+)$ & $0,111(+)$ \\
\hline Dual inoculation, CVEV then CTV & $0,032(+)$ & $0,045(+)$ & $0,008(-)$ \\
\hline Simultaneous inoculations of CTV and CVEV & $0,054(+)$ & $0,0076(+)$ & $0,100(+)$ \\
\hline Grinding & blank & blank & blank \\
\hline NC & $-0,0015$ & 0,001 & $-0,008$ \\
\hline PC & 0,118 & 0,110 & 0,102 \\
\hline
\end{tabular}

Note: Measured with ELISA reader at $405 \mathrm{~nm}$. Threshold for a positive reaction on new plate> $2 x$ the negative control (Lamka, 1990). Negative (-) does not contain CTV and positive (+) contains CTV.

\section{DISCUSSION OF RESULTS}

Incubation period of CTV and CVEV Purut and Lime. The incubation period of vein clearing and cupping CTV (44 - 140 dai) and vein enation CVEV (86-142 dai) on Purut and Lime were relatively longer than the previously reported incubation period of CTV between 30-36 dai (Dwiastuti 2016) and CVEV between 60-90 dai at optimal temperature $24-27^{\circ} \mathrm{C}$ during the day and $18-21^{\circ} \mathrm{C}$ at night. During the study the temperature ranged between $28-$ $30^{\circ} \mathrm{C}$ at noon. This temperature difference is likely to cause disruption in the multiplication of the two viruses although plants tested were considered sensitive. Based on the reported biological description (EPPO / CABI, 1996 and Shen et al. 2016) CVEV symptoms are detected through chip budding grafted part in 5-8 weeks on the leaves of Lime (C. aurantiifolia), rough lemons (C. jambhiri) or sour orange (C. aurantium).

In the field, Purut is often found infected by CVEV and CTV with mild to moderate infections, but in this study, it is known that the incubation period of the disease symptoms of CTV and CVEV on Lime occurred more rapidly than on Purut. These results are in line with a report by Vidalakis et al. (2010) which states that Lime is the most susceptible host for the two diseases. Therefore, in the routine test for disease indexing, Lime is used as a respective plant indicator.

Effect of single and dual inoculation on the expression of symptoms and the percentage of CTV and CVEV attack on two citrus species. Two or more viruses can infect the same plant within the same or different tissue or organ. In non-related viruses, synergistic interactions generally occur, the virus infects together and cause more severe symptoms than a single infection. In contrast, related viruses will have interactions or competition in which one of the viruses will be dominant (Pallas \& Garci'a 2011; Folimonova 2013). CTV and CVEV are not related. CTV is closterovirus, has flexuous particle with a length of 2000 $\mathrm{nm}$ and a diameter of $12 \mathrm{~nm}$ (Sastry 2013) which consists of single molecule of single stranded RNA, included in family Closteroviridae (Hilf et al. 2005, Svetlana, et al., 2010, Folimonov et al. 2007). Meanwhile, CVEV is a virus with spherical shape and has a diameter of 22-24 nm (Vives 2013), included in family Luteoviridae.

In this study, synergistic interaction occurred in the dual inoculation of CTV then CVEV, as well as CTV and CVEV simultaneous inoculation, which causing them to express more severe symptoms of the two viruses (vein clearing, vein cupping and vein enation) in Lime, and some symptoms in Purut. In the treatment of dual inoculation CVEV then CTV by bark grafting method, in interval of 1 month, the sinergy expression became lessen. The complex 
of symptoms was reduced. Based on its size, CTV is assumed more capable in penetrating parenkhim towards phloem tissue and replicates there by using the host's metabolism and translocation which are faster than CVEV. There could be competition in time as well, which means viruses that enter first will be able to develop faster. The results are consistent with previous research (Vidalakis et al. 2004) on infection of CPsV (Citrus psorosis virus) and CVEV that carried out after CTV infection which showing reduced expression of CVEV and no CPsV symptom. This suggests that the variability in the expression of symptoms may also be influenced by the time of initiation of infection.

Result of ELISA test of CTV. The basic principle of ELISA is serology test, which involves the use of enzymes and immunosorbent, in which the enzymatic reaction will occur between the antibody and the corresponding antigen. This study used antibody of CTV, means that the one will be detected is CTV content in the tested sample (antigen) which can be tracked with the addition of the enzyme catalyzing the alkaline phosphatase substrate which then at the end point will show the color changing (yellow compound). The intensity of the color gives an indication of the amount of antibody or antigen binding (Albersio et al. 2012). In the treatment of single CVEV, no CTV can be detected.

Effect of single and dual inoculation of CTV and CVEV on Plant Growth. In studies by Hipper et al. (2013) and Roossinck (2013), plant virus is obligate intracellular parasite that live exclusively and relies on its host to complete its life cycle, starts from replication, encapsidation, cell to cell movement and long-distance transport. The virus swiftness on using food supplies in plant, such as photosynthesis product, is required for the virus to survive and this causes the crops suffer due to lack of food which expressed as chlorosis symptoms as well as interferes with plant growth. Gosalvez-Bernal et al. (2008) suggested that the pathogen often causes unbalance of plant hormonal system which then showed as different growth response of the plant from the healthy plant. The spread of the virus in the body of plants varies greatly, depending on: the type of virus, host plants, and the interaction between them.

Pazarlar et al. (2013) and Perez-Clemente et al. (2014) mentioned that the virus generally causes a decrease in photosynthesis through a decline in the number of chlorophyll per leaf area, decreased chlorophyll efficiency which then inhibit the growth of leaves and plant growth including the formation of new leaves. In the limited-to-phloem group of viruses, transport of nutrients from the roots to the leaves is disrupted because phloem tissue clogged by accumulation of viral particles (Hipper et al. 2010)

The effect of this viral infection may also be affected by the infection rate during the period of young plants. These results are consistent with the observations of Taiwo and Owolabi (2001) on the Celosia mosaic virus on Celosia argentea L. that the younger the plant at the time of infection, the more severe symptoms of the disease and the greater the effect on the growth and yield (Langham et al, 2005; Kareem and Taiwo, 2007; Taiwo et al., 2007).

From these results it can be concluded that the Lime species is more susceptible to single infection of CTV, of CVEV or three combinations of dual inoculation of CTV and CVEV. Single inoculation of CTV and dual inoculation of CTV and CVEV, either simultaneously or consecutively showed effect on the percentage of infected plants, more numerous and complex variations of symptoms, greater absorbent value of Elisa test, as well as the number of leaves and leaf area.

\section{REFERENCES}

1. Albersio J, Lima A, Aline Kelly Q. Nascimento, Radaelli P and. Purcifull DE 2012. Serology Applied to Plant Virology, Serological Diagnosis of Certain Human, Animal and Plant Diseases, Dr. Moslih Al-Moslih (Ed.), ISBN: 978-953-51-0370-7, InTech, Available from: http://www.intechopen.com/books/serological-diagnosis-ofcertain-human-animaland-plant-diseases/serology-applied-to-plant-virology 
2. Da Graça; Sétamou M.; Skaria, M. and French J. V. 2007. Arthropod Vectors of Exotic Citrus Diseases: A Risk Assessment for the Texas Citrus Industry. Subtropical Plant Sciemce. Texas. p. $64-74$.

3. Dwiastuti, ME 2016. Prevent the threat of citrus systemic diseases: Revitalize the glory of local citrus. IAARD press. Jakarta. Indonesia. 77 p. (in Bahasa Indonesia)

4. Dwiastuti ME \& Wuryantini S. 2014. Evaluasi Kesehatan Benih Pada Alur Proses Produksi Dan Adopsi Teknologi Benih Jeruk Bebas Penyakit Di Pusat Perbenihan Jeruk Di Kabupaten Kampar, Propinsi Riau. Laporan hasil penelitian on top. Balitjestro. $16 p$

5. Eppo/Cabi 1996. Citrus Tristeza cloterovirus in: Quarantine pest forurope, 2nd edition (Ed. By Smith IM, McNamara, DG, Scott PR, Holdermess M) CAB Internasional, Walingford, UK

6. Folimonov AS, Svetlana Y. Folimonova, Bar-Joseph M, Dawson WO.2007. A stable RNA virus-based vector for citrus trees. Virology 368 (2007) 205-216

7. Folimonova SY.. 2013. Developing an understanding of cross-protection by Citrus tristeza virus. Frontiers in Microbiology | Virology April 2013 vol. 4 (76) 1-9

8. Hančević K., Černi S., Radić T., Škorić D. 2012. Comparison of diff erent methods for Citrus tristeza virus detection in Satsuma mandarins. Journal of plant diseases and protection. 119: 2-7.

9. Hipper C, Brault V, Ziegler-Graff $V$ and Revers F. 2010. Viral and cellular factors involved in phloem transport of plant viruses. Frontier in Plant scince www.frontiersin.org May 2013 (Volume 4) Article 154: 1 - 24

10. Hilf, M. E. and Garnsey, S. M. 2002. Citrus Tristeza Virus in Florida: A Synthesis of Historical and Contemporary Biological, Serological, and Genetic Data. Fifteenth IOCV Conference. p. $13-20$.

11. Jiangfeng Shen, XianChen, JianpingChen \& Liying Sun. 2016. A phloem-limited fijivirus induces the formation of neoplastic phloem tissues that house virus multiplication in the host plant. Scientific Reports | 6:29848 | DOI: 10.1038/srep29848. OPEN www.nature.com/scientificreports/1-9

12. Karasev, A. V.; Boyko, V. P.; Gowda, S.; Nikolaeva, O. V.; Hilf, M. E.; Koonin, E. V.; Niblett, C. L.; Cline, K.; Gumpf, D. J.; Lee, R. F.; Garnsey, S. M.; Lewandowski, D. J. and Dawson, W. O. 1994. Complete Sequence of the Citrus Tristeza Virus RNA Genome. Virology 208. p. $511-520$.

13. Kareem, K.T. and Taiwo, M.A. 2007. Interaction of viruses in cowpea: effect on growth and yield parameters. Virology Journal. 4: 15

14. Lamka, G. L. 1990. Development of an immunosorbent assay for seed-borne Erwinia stewartii in corn seed. Lowa State University.

15. Langham, M.A.C., Cihlar-Strunk, C.L. and Hoberg A.E. 2005. Evaluation of high pressure spray inoculation of Bean pod mottle virus on yield and test weight of Soybean. Phytopathology. 95:164

16. Meziane M. , Frasheri D. , Carra A. , Djelouah K., Carimi F. , D’Onghia A.M.. 2009. Citrus sanitation methods for the elimanition of Citrus tristeza virus (CTV) Options Méditerranéennes B 65: 177 - 180

17. Owolabi, A. T. and Taiwo, M.A. 2001. Effect of Celosia mosaic virus on Celosia argentea L. Global J. Pure and Appl. Sci. 7 (2): 209-212

18. Pallas V and Juan Antonio Garci'a JA. 2011. How do plant viruses induce disease? Interactions and interference with host components .Journal of General Virology (2011), 92, 2691-2705

19. Pazarlar S, Gümüş M, Öztekin Gb. 2013. The Effects of Tobacco mosaic virus Infection on Growth and Physiological Parameters in Some Pepper Varieties (Capsicum annuum L.). Not Bot Horti Agrobo, 2013, 41(2):427-433

20. Perez-Clemente, RM, Montoliu, Vives, V, Lopez-CLiment M. F. and Gomez-Cadenas A. 2014. Photosynthetic and antioxidant responses of Mexican Lime (Citrus aurantifolia) plants to Citrus tristeza virus infection. Plant Pathology (2014) a 2014 British Society for Plant Pathology: 1-9 
21. Roossinck MJ. 2013. Plant Virus Ecology. PLOS Pathogens Volume 9 Issue 5 e1003304. www.plospathogens.org

22. Sastry, K. S. 2013. Plant Virus and Virois Diseases in the Tropics. Springer Science Business Media. Vol. 1. p. 11-97

23. Su, H.J. 2008. Production and Cultivation of Virus-free Citrus Saplings for Citrus Rehabilitation in Taiwan. Asia-Pacific Consortium on Agricultural Biotechnology, New Delhi and Asia-Pacific Association of Agricultural Research Institutions, Bangkok. P $51+i x$.

24. Setha, V \& Su, HJ. 2011. Controlling Citrus Huanglongbing (HLB) for the rehabilition of Citrus Orchard in Cambodia. International Journal of Environmental and Rural Development (2011) 2-2: 6-12

25. Supriyanto, A\& Whittle, AM 1997. Citrus Rehabilitation in Indonesia. Eleventh IOCV Conference. Pp: $409-411$

26. Taiwo, M.A., Kareem, K.T., Hughes, J d' A and Nsa, I.Y. 2007. Cowpea viruses: Effect of single and mixed infection on symptomatology and virus concentration. Virology Journal. 4:95.

27. Vidalakis, G. et al 2004. Efficacy of Bioindexing for Graft-Transmissible Citrus Pathogens in Mixed Infections. Departmenent of Plant Pathology, University of California, USA. Vol.8. No. 12

28. Vidalakis G, da Graça J, Dixon W N, Ferrin D, Kesinger M,.Krueger, Lee RF, Melzer MJ, John Olive J , Polek ML, Peggy J. Sieburth PJ, Williams LL and Wright GC. 2010. Citrus quarantine sanitary ang sertification program in the USA: Part I Citrus quarantine and introduction. Citrograph May/June 2010: 26 - 39

29. Vives, MC, Velázquez, K., Pina, JA, Moreno, P., Guerri, J \& Navarro, L 2013. Identification of a New Enamovirus Associated with Citrus Vein Enation Disease by Deep Sequencing of Small RNAs 2013 The American Phytopathological Society. Vol. 103, No. 10, 2013: $1077-1086$ 